"Assessing service quality in online banking services"

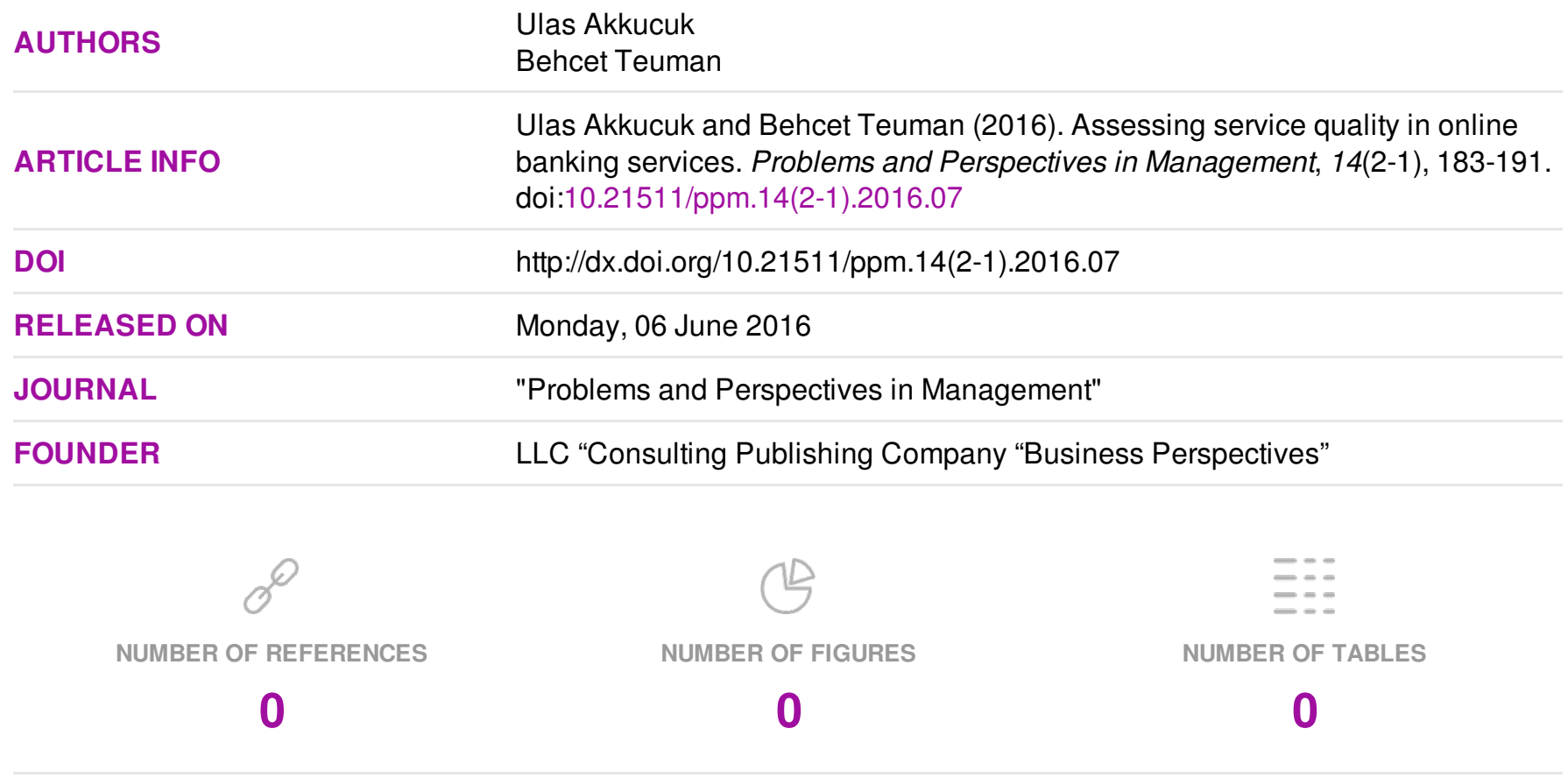

(c) The author(s) 2023. This publication is an open access article. 
Ulas Akkucuk (Turkey), Behcet Teuman (Turkey)

\title{
Assessing service quality in online banking services
}

\begin{abstract}
Service quality and the effective measurement of service quality on the Internet have been drawing much attention lately with the increasing use of the World Wide Web. Researchers and managers focus on the construction of scales to measure electronic service quality, which assess customer satisfaction and loyalty as an ultimate goal. E-S-Qual is the most recently developed and popular e-service quality measurement technique on which there are quite a number of research studies. In this study, existing literature on service quality scales and the E-S-Qual scale is reviewed. A modified scale is also proposed suitable for the online banking sector.
\end{abstract}

Keywords: SERVQUAL, banking, E-S-Qual, financial services.

JEL Classification: M31, G21, M15.

\section{Introduction}

The effective measurement of service quality on the Internet is drawing much attention lately with the increasing use of the World Wide Web. E-S-Qual is the recently developed and popular e-service quality measurement technique on which there are quite a number of testing efforts (Boshoff, 2007; Connolly \& Bannister, 2008; Swaid \& Wigand, 2009; Connolly, Banister \& Kearney, 2010; Marimon, Vidgen, Barnes, \& Cristobal, 2010; Akınc1, Atılgan-İnan, \& Aksoy, 2010). The E-S-Qual scale is not fully compliant with Internet banking services and it needs to get adapted to align with the e-banking features. The main objective of the study is to review the literature and propose an adapted E-S-Qual model particularly aimed at measuring the satisfaction of customers using online banking services.

Internet banking is a self-service technology (SST). Nowadays, Internet banking transactions are developed to a point that almost all banking transactions can be executed online by the customers themselves with the exception of cash withdrawals and cash deposits using banknotes and coins. Competition in the banking industry has become severe, just as in the other sectors of the economy. Globalization has been sped up with the borderless finance sector. The impacts of globalization and financial crisis in the markets have decreased the bank's profit margins due to the increasing cost of risk (loan defaults) and competitive pricing. Consequently, banks have focused on risk and cost management issues more than they have done in the past.

Leveraging transaction per employee is crucial and encourages the deployment of SSTs (self-service technology) in the banking sector. In the meantime, providing Internet banking services becomes inevitable in acting as a global financial service provider for the customers located in different

(C) Ulas Akkucuk, Behcet Teuman, 2016.

Ulas Akkucuk, Ph.D., Associate Professor of Quantitative Methods, Department of Management, Bogazici University, Istanbul, Turkey.

Behcet Teuman, BIS Solutions, Istanbul, Turkey. geographies. Besides the banks' intention to promote SSTs like Internet banking and ATMs (Automated Teller Machines), there are factors driving customers to prefer self-service alternatives. Internet banking service is superior on branch, ATM, kiosk-banking service with its anytime, anywhere functioning.

Several studies about the adoption of Internet banking in various countries have agreed on the same set of factors as the motivators to customers' preference of banking transactions on the web. Tan and Teo (2000) completed a study about attitudinal, social, and perceived behavioral control factors that would influence the adoption of Internet banking three years after the Internet banking business started in Singapore. The theory of planned behavior (TPB) framework (Ajzen, 1991) postulates that a person's intention to adopt Internet banking is determined by three factors, i.e., (1) attitude, which describes a person's perception towards Internet banking, (2) subjective norms, which describe the social influence that may affect a person's intention to use Internet banking, and (3) perceived behavioral control, which describes the beliefs about having the necessary resources and opportunities to adopt Internet banking. Tan and Teo's (2000) findings have shown that intention to adopt Internet banking services could be predicted by attitudinal and perceived behavioral control factors, but not by subjective norms, probably because Internet banking was very new in Singapore. The attitudinal factors that are significant include relative advantage, compatibility with respondent's values, experience, and needs, trialability (the level of cost and riskiness of the trial of the service), and risk.

Ming-Chi (2009) tested TAM and TPB models in a study held in Taiwan and the results indicated that the intention to use online banking is adversely affected by the security/privacy risk, as well as the financial risk and is positively affected by perceived benefit, attitude and perceived usefulness. Modified TAM model with the introduction of perceived risk 
and trust was tested in South Korea by Lee, Lee, and Kim (2007). They were confident that both perceived usefulness and trust had important effects on the adoption behavior of mobile banking. Perceived risk, however, had an indirect effect on adoption behavior even though it had an insignificant direct relationship with adoption behavior. Perceived risk was identified to exert a strong inhibiting influence on trust.

Malaysian consumers adopted the use of Internet banking because of hedonic oriented Internet banking sites, the perceived importance of Internet banking to banking needs and compatibility factors (Suki, 2010). Dixit and Datta (2010) have put forward recommendations for banks which serve Indian adults older than the age 35. Banks should (1) ensure that online banking is as safe and secure as traditional banking, (2) organize seminars and conferences about security and privacy issues, (3) emphasize the convenience of using online banking (4) provide additional cost savings. They have explored five factors: security-privacy, trust, innovativeness, familiarity, and awareness. Security-privacy is discovered as the most influential factor for the acceptance and intention to use of Internet banking.

El-Kasheir, Ashour, and Yacout (2009) have identified "ease of use" as the only significant predictor of intention to continue to use Internet banking services in their study in Egypt. An example of the studies on the same subject was carried out in Turkey (Durer, Özsüzgün-Çalışkan, Akbaş, \& Gündoğdu, 2009). In the exploratory analysis conducted in this work, factors extracted for decision to use Internet banking services include services and products, security, time convenience, cost and recovery, design and speed. Security and time convenience are the most critical factors on the decision of using internet banking services. "Trust in bank", "secure internet web site", and "protection of customer's private information" are the measures of security. "Transactions without waiting in queue", "anytime account and transaction monitoring", and "no working-hours restriction" are the items under the time convenience factor. Factors for the decision not to use Internet banking are identified by Durer et al. (2009) as difficulty in use and cost, security problems, difficulty in adoption of technology, unbreakable habits. In the same study, the most frequent problem encountered in Internet banking is the loading speed of the pages. Services not satisfying the customer need, complexity of use, insufficient support and compensation in the recovery processes are among the other problems frequently encountered.

The convenience of internet banking elevates the shift in the physical money exchanges to banking via internet by lowering the risk of carrying cash, and every day, more transactions take place in the virtual environment. Now, banks promote mobile banking to increase the convenience of e-banking by eliminating the requirement of personal computers and internet connections. Therefore, better measuring instruments for customer satisfaction and loyalty is becoming essential for the banks in the Internet and mobile banking services.

\section{Literature review: service quality}

There have been extensive studies conducted on service quality for the last 30 years. However, electronic service quality studies are quite new and have been on the rise in the last 10 years. Parasuraman, Zeithaml, and Malhotra (2005) have named non-Internet based servicing as traditional. Traditional service quality is mainly based on the comparison of customer expectations and company offerings (performance) in the customer interactions and experiences with the company. The comparison displays either a positive or a negative gap and this gap represents the satisfaction level of the customer in the transaction.

A well-known, generally accepted, and multipleitem scale for measuring consumer perception of service quality measure, SERVQUAL has been developed by Parasuraman, Zeithaml, and Berry (1988). This scale was originally developed for nonweb based service settings, before the Internet era.

Before the development of the SERVQUAL, there were studies investigating the meaning of service quality. Weitz and Wensley (1985, p. 340) have counted the following studies as examples of such preliminary works: Sasser, Olsen and Wyckoff (1978), Grönroos (1982), Lehtinen and Lehtinen (1982), Lewis and Booms (1983). There were discussions on quality, satisfaction, and attitude. Definition of the perceived quality is simply the degree and direction of the discrepancy between expectation and perception in Expectancy-Disconfirmation theory perspective. Expectations are interpreted as desires or wants of the consumer. Perceived quality like attitude is an overall attitude but different than satisfaction which is related to specific transactions. Attitude is constructed after accumulation of series of (dis)confirmation experience and as Oliver (1981) stated satisfaction soon decays into one's overall attitude towards purchasing products.

In their work, Parasuraman et al. (1988) have focused on five different service categories: appliance repair and maintenance, retail banking, long distance telephone, securities brokerage, and credit cards. Observations are limited to 40 in each service category and 200 respondents were surveyed with 97-item, 10-point scale questionnaire. Each 
question was asked two times: first, the Perception of the service performance of the entity, second the Expectation of the respondent in 7-point Likert scale. The difference between the scores of two questions (P-E) is used as the measure of the quality of service delivered. After Cronbach alpha tests of indicators of the sample collected, 54 items have been selected for a reliable construct. Exploratory Factor Analysis (EFA) has been conducted with oblique rotation; it has revealed better solution than orthogonal rotation. The number of valid indicators first decreased to 34 items on 7 factors and then, by checking the validity of model on different sub-sets of four firms' data, 22 items on 5 factors model were constructed. 10 dimensions which were conceptually constructed before the EFA work did not disappear totally, but five of them were combined into two other factors.

SERVQUAL scale is reliable, valid, and applicable for broad spectrum of services scale. Retailers can use the scale to understand the expectations and perceptions of their customers. The periodic application of the scale helps to monitor the trend in service quality, clustering of customers with their expectations, detection of relative importance of the factors for specific category of the service. The improvement of the service with the interpretation and acting based on the outputs of the scale is attracting managerial attention and the use of SERVQUAL.

\section{Literature review: E-service quality measurement}

Remote format of service delivery brings significant changes in customer interaction and behavior (Broderick \& Supatra, 2002). The quality perception process has five key elements (1) customer expectation of the service, (2) image and the reputation of the service, (3) aspects of service setting, (4) the actual service encounter, and (5) customer participation.

The service setting is perhaps the most obvious element which has an effect on the perceived value. This setting (website) is virtual on the Internet. The web site features like content, design, download speed, navigation and security impact customers' value perception. Broderick and Supatra (2002) define service encounter dimensions as temporal duration, affective or emotional content and the spatial proximity of service provider and customers. For Internet banking, human interaction and intimate spatial proximity is considered to be low. However, before deciding to use the services of a specific bank, there is a high level of communication at branches, through e-mail and over the Internet. The degree of self-determinism permitted to customers and how they participate are the key inputs to perceived service quality (Broderick \& Supatra, 2002).
Findings of Broderick and Supatra (2002) have shown that customers' expectations are generally in the adequate level of service rather than ideal or desired level, because research has been done in the early stages of Internet banking. Image and reputation did not emerge as important factors for respondents. Key expectations were ease of use, good navigation, and strong interactivity and early response to service actions. Traditional concepts such as reliability, responsiveness, and assurance have had impact on service quality. The most immediate impact in service evaluation was cues in the service setting and events in the service encounters. Problems such as slowness, poor navigation capabilities, and interactivity in service setting, lack of help and empathy in the service encounters trigger negative word of mouth and switching of the service providers. Design and content have fewer comments in the Broderick and Supatra's (2002) study.

Broderick and Supatra (2002) have identified four roles for Internet banking users and scripts for these roles are in Table 1.

Table 1. Roles of Internet users

\begin{tabular}{|l|l|}
\hline & \multicolumn{1}{|c|}{ Roles of Internet users } \\
\hline Role1 & Activating the service setting (Logging on to web site) \\
\hline Role2 & Initiating one-to-one service encounter \\
\hline Role3 & Finalizing the service transaction via the web site \\
\hline Role4 & Confirming a completed service transaction \\
\hline
\end{tabular}

The customer is asked to integrate different scripts by himself. It is customer's responsibility to initiate the process and conform to finalize it. If the next step is unclear, customers need to interpret different signals and cues in the web site and to know what should be the next script, which is not clear in Internet banking. Customers then choose to execute traditional scripts such as branch visits, asking via e-mail. Four roles described above have a key function in the satisfaction or dissatisfaction of customers.

Parasuraman, Zeithaml and Malhotra (2005) indicated that the way people perceive the service quality in web-based settings differs from service quality in brick and mortar settings. This is due to the fact that the acceptance and usage of technology are not evenly distributed among customers.

There were studies to develop a suitable measurement scale for the evaluation of websites. The studies completed until the work of Parasuraman et al. (2005) did not cover the full cycle of exchange on the web. Complete coverage of e-purchase and post interaction service aspects are covered by the model called E-S-Qual and developed by Parasuraman et al. Examples of major scholarly scale development studies on e-service quality measurement before E-S-Qual are in Table 2. 
Table 2. E-service quality studies

\begin{tabular}{|l|}
\hline WebQual (Loiacono, Watson \& Goodhue, 2000) \\
\hline WebQual (Barnes \& Vidgen, 2001) \\
\hline SITEQUAL (Yoo \& Donthu, 2001) \\
\hline e-Satisfaction (Szymanski \& Hise, 2000) \\
\hline eTailQ (Wolfinbarger \& Gilly, 2003) \\
\hline
\end{tabular}

WebQual, developed by Loiacono et al. (2000), was constructed to help web designers and it does not measure service quality. The scale measures web sites in 12 dimensions which might influence customer satisfaction but does not measure anything related to purchase experience and direct service quality (Parasuraman, Zeithaml \& Malhotra, 2005). Response time, informational fit to task, design, interaction, intuitiveness, and business process are examples of the dimensions. The customer service dimension is excluded because of the design of research methodology that only asks students to evaluate the sites they have visited without the experience of purchasing.

Another scale developed by Barnes and Vidgen (2001), which is also called as WebQual, measures the weighted customer perceptions in five dimensions: usability, design, information, trust, and empathy like the previous scale, data collection in this work did not entail real purchase experiences.

SiteQual by Yoo and Donthu (2001) has four dimensions (ease of use, aesthetic design, processing speed and security) measured in nine items. This measure was constructed with the data collected from the students who interacted with three web sites but without completing the whole purchasing process. The perceived value of the exchange process was lacking in this operationalization.

Syzmanski and Hise's (2000) attempts were criticized since they dealt with web site aspects' satisfaction of the customer more than the customer service and fulfillment. eTailQ developed by Wolfinbarger and Gilly (2003) have 14 items in four factors: web site design (including personalization aspects), reliability/fulfillment (accurate information and delivery of promised services and goods), privacy/security, customer service (recovery and help). Their construct has resemblance to E-S-Qual study of Parasuraman et al. (2005) study. Web site design and customer service dimensions are less internally consistent and less distinct.

A preliminary E-S-Qual study by Zeithaml, Parasuraman, and Malhotra (2002) has benefited from the previous e-service scale developments. The model abbreviated as E-SQ has five dimensions after analysis: (1) information availability and content, (2) ease of use, (3) privacy/security, (4) graphic style, and (5) reliability and fulfillment.
Later, Parasuraman, Zeithaml, and Malhotra refined their previous E-SQ scale in 2005 which covers all phases of web based purchasing transactions: shopping, purchasing and delivery. They have used focus groups and evaluated responses of focus groups. They have proposed a theoretical framework to understand consumers' cognitive structures. In this framework, perceptual attributes of web sites are differentiated from more obvious concrete cues. Concrete technical attributes may change in time; however, abstract perceptual attributes do not change. These perceptual attributes are the global assessments and have direct influence on actual behavior. Perceptual attributes are more experimental than technical and can be easily assessed by customers and can be rated easily than other technical cues which consumers might not be aware of or be assessed easily.

The initial scale was formed with 121 items in the Parasuraman et al. study in 2005. E-SQ scale's 11 dimensions have been reduced to 4 with 22 items after EFA. Efficiency, fulfillment, system availability and privacy are the factors of the new model: E-S-Qual scale. Different scale for the recovery process for the customers who have encountered problems during purchasing process has been developed: E-RecS-Qual. It is an 11-item, 3-factor (responsiveness, compensation, and contact) model.

The theoretical framework of E-S-Qual and E-RecSQual has made the items easily measured without questioning technical details of web sites. Respondents can easily express their general perception or opinion about the service setting without knowing or exploring the technical aspects of the web site and feedback purchasing experience in the service encounter and post purchase interactions, i.e., delivery and recovery process in case of problems.

Parasuraman et al. (2005) have conducted Confirmatory Factor Analysis (CFA) following the Exploratory Factor Analysis (EFA) with different sample and they have shown goodness-of-fit signals of their model.

A study completed after the work of Parasuraman et al. (2005) was achieved by Bauer, Falk, and Hammerschmidt (2006). They have suggested a conceptual transaction process-based framework in order to capture all relevant quality aspects of the virtual service transaction. They have subdivided purchasing process into four transaction stages. It is aimed to improve the measurement of service quality by grouping user activities into stages by the support of task completion approach. The first stage is the information stage in which market offerings are examined and compared. Next is the agreement stage where market participants negotiate and 
conclude the contract. The fulfillment stage deals with the exchange of goods and services. Finally, the after sales stage addresses the importance of relationship related activities. Each of the tasks within the four stages must be completed for service delivery to take place. With this approach, it is expected to receive detailed information for improving service quality.

Bauer et al. (2006) have tried the E-S-Qual model with the introduction of two new factors: responsiveness and enjoyment. They have combined some E-S-Qual factors into the new factors in their new construct called as eTransQual. System availability and efficiency factors in E-S-Qual were joined under one factor they called as process. The remaining efficiency items of E-S-Qual have been classified under functionality/design factor of eTransQual. Fulfillment and privacy items of E-S-Qual were combined into the factor called reliability.

Bauer et al. (2006) criticized the Parasuraman et al. (2005) work because of missing hedonic service quality elements which are intangible and emotional. They have considered that Parasuraman et al. (2005) measurement of shopping experience was solely based on the utilitarian benefits. The perceived fun of using the web site and the personalization of content and features in the first stage seem to be important quality criteria for Bauer et al. (2006) and they have constructed enjoyment latent variable with personalization of service, fun of using web site, excitement when shopping online, entertainment provided by website. They have also inserted the responsiveness factor which is originally in E-Recs-Qual model of Parasuraman et al. (2005) into the service quality measure. Responsiveness is measured with alternative communication channels' availability, return policy, and prompt reaction for the requests indicators. They have considered responsiveness is relevant to service quality and independent of actual problems.

In Bauer et al. (2006) study, 53 quality measures were ended with 25-item, 5-factor eTransQual model. However, the model had the problem of having not distinct factors. It was failed with Fornell and Larcker's (1981) discriminant validity test. Functionality/design, process, and reliability factors do not show that they were distinctively measuring the service quality, i.e., average variance among factor indicators is less than inter-factor correlations. Similarly, covariances of reliability factor with functionality/design and process factors are higher than the average of reliability indicators' variances that could be explained by reliability. These are indicators of the lack of proper factor construction.
eTransQual model has shown good values for comparative fit indices. However, it had poor fit with the population when the error of approximation index 4 was considered $(\mathrm{RMSEA}=.1)$. eTransQual quality measurement model requires further investigation on both the design and test steps before the use.

After 2005, many researchers have focused on E-SQual and E-RecS-Qual models and tested the validity of the model. Although they have respecified the model for different service settings, different service categories and cultures, many of them agreed that the most effective scale to measure the quality of service offered by the Internet retailers is the E-S-Qual. They recommend E-S-Qual for use in managerial purposes.

Boshoff (2007) has achieved his testing on an Internet web site selling books and music (DVDs, CDs) online. He has discovered 5 and 6 factor solutions in his exploratory factor analysis. He then compared original 4 factor model, 5, and 6-factor models in the confirmatory work. Boshoff (2007) has concluded that six factor model fits better to his sample. Three items related to speed in efficiency and system availability factors were moved under a new factor he called as Speed. Three items under fulfillment factor related to delivery of promised product/services timely and accurately were moved under a new factor: Reliability. Boshoff (2007) suggested further exploration of the reliability factor that has particular importance in the delivery process of tangibles. In his study, reliability is the strongest predictor of value perceptions.

Boshoff (2007) concluded that "E-S-Qual instrument is a valid and reliable instrument to measure service quality in an electronic shopping environment". Marimon, Vidgen, Barnes, and Cristobal (2010), have tested the applicability of E$\mathrm{S}$-Qual in Spain for a supermarket. They have respecified the model with 15 items and 4 factors by the analysis on a sample total of 113 observations. Factors and indicators of re-specified model are as follows: 3 items in efficiency factor, 4 items in system availability (SYS1 indicator removed, EFF5 loaded by system availability not by efficiency), 5 items in fulfillment, and 3 items in privacy.

Reliability tests of factors were passed. However, six of the indicators had lower loading coefficients than the acceptable level $\left(\lambda=.707, \lambda^{2}=.50\right.$; Fornell and Larcker, 1981) and re-specified model has shown severe convergent validity problems. In the meantime, they have discovered that high levels of loyalty are positively related to high level of purchases and efficiency and privacy factors have no impact on perceived value. 
Another re-assessment of E-S-Qual study, which was conducted in Turkey on Internet banking service, was accomplished by Akınc1, Atılgan-İnan, and Aksoy (2010). Akınc1 et al. (2010) have adapted the E-SQual scale for Internet banking which is a pure service setting. Indicators related to delivery of products were eliminated because of inapplicability to Internet banking. There were enhanced and reconstructed items in adapted scale of Akinc1 et al. (2010). They have conducted CFA on 20-item on 4factor E-S-Qual scale. Details of Akınc1 et al. (2010) scale are explained in detail later in this study. Adapted E-S-Qual scale passed goodness-of-fit tests but failed in discriminant validity tests for the sample of Akınc1 et al. (2010). 12 items were removed to ensure the validity of the model both for the whole sample and the sub-groups composed of major banks' observations. The re-specified model for Internet banking has 4 factors and 2 items under each factor. Fit statistics have suggested adequate model fit for the re-specified E-S-Qual model of Akinc1 et al. (2010) and the model has passed convergent, discriminant validity and reliability tests.

Similarly, the E-RecS-Qual scale was adapted for Internet banking. The original model that has 11 items on 3 factors is operationalized with 8 items on 3 factors after Internet banking adaption. Reliability and validity tests are passed and without any respecification effort, adapted E-RecS-Qual model has indicated an acceptable fit of the model to the sample. Akınc1 et al. (2010) indicated that both scales provide evidence for reliability and validity issues and findings supported the four-dimensional electronic service quality and 3 dimensional electronic recovery service qualities constructs on a different service setting.

\section{Modified E-S-Qual scale for online banking}

The construction of the scales to measure service quality for Internet banking is mainly based on the model E-S-Qual (Parasuraman, Zeithaml \& Malhotra, 2005). Later, Akınc1 et al. (2010) have adapted Parasuraman et al. (2005) electronic service quality measurement model for banking.

Akıncı et al. (2010) have also re-assessed E-Recs-Qual scale which is covering service problems, the solution of these problems and perception of the customers in the recovery process. It is considered as valuable customer information, which brings new perspective on service recovery issues. Akınc1 et al. (2010) have inserted branching question for the respondents who have encountered problems in the Internet banking services and asked for recovery. In contrast to many services delivered over the Internet, there is no exchange of tangible goods in the banking transactions. The main triggers of recovery process are sale of out-of-stock goods, defaults on delivery packaging and delivery times longer than promised and other problems of after sales services. However, transactions over the Internet banking are real-time and online. There are cases to be encountered in the Internet banking such as communication breakdown, site crashes, or unlucky searches of information on the site, which are also problems of other web sites selling tangible products. Therefore, recovery instances can be expected less in pure service settings like Internet banking than other web-shopping sites selling tangibles.

Original E-S-Qual scale was adapted by Akıncı et al. (2010) for Internet banking services either by removing irrelevant questions or adapting questions or reconstructing new ones. E-S-Qual model has 22 questions in four dimensions: 1) Efficiency (8 questions), 2) System availability (4 questions), 3) Fulfillment (7 questions), 4) Privacy (3 questions).

Efficiency dimension contains items, which measure the ease of use and speed of the Internet site. In this study, we propose the original E-S-Qual efficiency factor questions with some adaptation or addition. The EFF4 question is enhanced by explanatory additions without changing its meaning. The EFF7 question is elaborated to measure how easy the signin process is. It is aimed to distinguish the EFF7 question from the EFF5 and SYS2 (Web site launches and runs right away). The original E-SQual and these two elaborated questions can be found in Table 3.

Table 3. Efficiency questions (EFF)

\begin{tabular}{|c|c|c|}
\hline & E-S-Qual & Proposed \\
\hline EFF1 & $\begin{array}{l}\text { This site makes it easy } \\
\text { to find } \\
\text { what I need. }\end{array}$ & Same \\
\hline EFF2 & $\begin{array}{l}\text { It makes it easy to get } \\
\text { anywhere on the site }\end{array}$ & Same \\
\hline EFF3 & $\begin{array}{l}\text { This site enables me to } \\
\text { complete a transaction } \\
\text { quickly }\end{array}$ & Same \\
\hline EFF4 & $\begin{array}{l}\text { Information at this site } \\
\text { is well organized }\end{array}$ & $\begin{array}{l}\text { Customer/product/transaction/market } \\
\text { information at this site is well organized. }\end{array}$ \\
\hline EFF5 & It loads its pages fast & Same \\
\hline EFF6 & $\begin{array}{l}\text { This site is simple to } \\
\text { use }\end{array}$ & Same \\
\hline EFF7 & $\begin{array}{l}\text { This site enables me to } \\
\text { get on to it quickly }\end{array}$ & $\begin{array}{l}\text { Authentication and authorization } \\
\text { process is completed easily and I can } \\
\text { get on to it quickly }\end{array}$ \\
\hline EFF8 & $\begin{array}{l}\text { This site is well } \\
\text { organized }\end{array}$ & Same \\
\hline
\end{tabular}

System availability questions measure the technical reliability of the Internet banking site. It has been considered that the questions in that factor are all applicable for Internet banking services and kept as the originals except with two small adaptations for Internet banking (Table 4). 
Table 4. System availability questions (SYS)

\begin{tabular}{|l|l|l|}
\hline & E-S-Qual & Proposed \\
\hline SYS1 & $\begin{array}{l}\text { Web site is always available for } \\
\text { business }\end{array}$ & Web site is always available \\
\hline SYS2 & $\begin{array}{l}\text { Web site launches and runs } \\
\text { right away }\end{array}$ & Same \\
\hline SYS3 & Web site does not crash & Same \\
\hline SYS4 & $\begin{array}{l}\text { Pages at web site do not freeze } \\
\text { after I enter my order } \\
\text { information. }\end{array}$ & $\begin{array}{l}\text { Pages at Web site do not } \\
\text { freeze after I click for a } \\
\text { transaction }\end{array}$ \\
\hline
\end{tabular}

Fulfillment indicators measure the level of satisfaction in the process of handling and executing customer orders as packing, shipping, and payments. Fulfillment items that test the quality of delivery process are not applicable for the services most in the Internet banking, because of zero-time delivery process, no tangible product delivery, no product deterioration or breakdown, no after-sales service, and no out-of stock situations in banking services. The FUL2, FUL3, and FUL5 questions are in this class and we suggest they be eliminated. For questions FUL4 and FUL6, re-constructed versions of Akinc1 et al. (2010) study are inserted. The FUL1 and FUL7 questions were enhanced with some explanations for better understanding of respondents. Finally, there were four questions inserted in the questionnaire under fulfillment factor (Table 5).

Table 5. Fulfillment questions (FUL)

\begin{tabular}{|c|c|c|}
\hline & E-S-Qual & Proposed \\
\hline FUL1 & $\begin{array}{l}\text { It delivers orders when } \\
\text { promised }\end{array}$ & $\begin{array}{l}\text { Transactions like EFT, mutual funds and } \\
\text { stock purchases are accomplished } \\
\text { within promised time-slots }\end{array}$ \\
\hline FUL2 & $\begin{array}{l}\text { This site makes item } \\
\text { available for delivery } \\
\text { within suitable time frame }\end{array}$ & Not applicable, eliminated \\
\hline FUL3 & $\begin{array}{l}\text { It quickly delivers what I } \\
\text { order }\end{array}$ & Not applicable, eliminated \\
\hline FUL4 & $\begin{array}{l}\text { It sends out the items } \\
\text { ordered }\end{array}$ & $\begin{array}{l}\text { My bank promptly informs about } \\
\text { important transactions through } \\
\text { preferred channels (SMS, call center, } \\
\text { e-mail, mobile application) }\end{array}$ \\
\hline FUL5 & $\begin{array}{l}\text { It has in stock the items the } \\
\text { company claims to have }\end{array}$ & Not applicable, eliminated \\
\hline FUL6 & $\begin{array}{l}\text { It is truthful about its } \\
\text { offerings }\end{array}$ & $\begin{array}{l}\text { Product/customer/transaction/market } \\
\text { records at my bank's web site are } \\
\text { always accurate }\end{array}$ \\
\hline FUL7 & $\begin{array}{l}\text { It makes accurate } \\
\text { promises about delivery of } \\
\text { products }\end{array}$ & $\begin{array}{l}\text { It makes accurate promises about } \\
\text { interest rates, banking fees, and due } \\
\text { dates }\end{array}$ \\
\hline
\end{tabular}

The Privacy questions measure the confidentiality of customer information and security of electronic transactions (Table 6). Questions PRI1, PR 2 are considered applicable for Internet banking. Question PRI3 (This site protects information about my credit card) is used as the original in Akınc1 et al. (2010) work. However, it is re-constructed in this study. Credit card is a payment tool in the Internet transactions and the theft of the card information causes financial loss to the holder. Generally, fee and interest payments of Internet banking services are directly debited in the demand deposits (current accounts) of the customers. But a few examples of payments made over the Internet banking using the credit cards are available. Internet banking customers realize financial losses not only by the theft of the credit card information; they can expose themselves to high risk of losses if their credentials (identification and password) are stolen. From this point of view, PRI3 (This site protects information about my credit card) is re-constructed as "My identification and password are well protected in my bank". In the study of Akınc1 et al. (2010), PRI3 is reconstructed as "I feel confident about the transactions I made at my bank's web site". This phrase is considered as reflecting another question measuring perceived transaction security and it is inserted as a new question (PRI4) into the questionnaire as Akınc1 et al. (2010). PRI2 is also modified, the term "other sites" is elaborated into any other bank or similar institution (could cover insurance company/pension company etc. as well as banks). As a result, four questions are presented under privacy factor.

\section{Table 6. Privacy (PRI)}

\begin{tabular}{|l|l|l|}
\hline PRI1 & \multicolumn{1}{|c|}{ E-S-Qual } & \multicolumn{1}{c|}{ Proposed } \\
\hline about my web-shopping & Same \\
\hline PRI2 & $\begin{array}{l}\text { It does not share my } \\
\text { personal information } \\
\text { with other sites }\end{array}$ & $\begin{array}{l}\text { It does not share my personal } \\
\text { information/transaction data with other } \\
\text { banks or institutions }\end{array}$ \\
\hline PRI3 & $\begin{array}{l}\text { My bank's web site } \\
\text { protects information } \\
\text { about my credit card }\end{array}$ & $\begin{array}{l}\text { This site protects information about my } \\
\text { Customer ID and password/PIN }\end{array}$ \\
\hline PRI4 & Does not exist & $\begin{array}{l}\text { I feel confident about the transactions I } \\
\text { made at my bank's web site }\end{array}$ \\
\hline
\end{tabular}

Overall there are 20 items in the proposed scale in this study, equal to the number of items in Akınc1 et al. (2010) and two less than in Parasuraman et al. (2005). Items of all E-S-Qual factors (efficiency, system availability, fulfillment and privacy) were measured with the 5-point Likert scale from $1=$ strongly disagree to $5=$ strongly agree. Parasuraman et al. (2005) and Akınc1 et al. (2010) have used the same scale. It is possible to experiment with 7-point or 6-point scales in a possible empirical analysis of the scale proposed in this paper.

\section{Conclusion}

This study primarily serves as a literature review of the important developments in service quality assessment and the particular applications in the electronic services industry. It also proposes a new scale for use in assessing the electronic banking services offered by firms. In doing so it modifies slightly a previous scale. In particular, the 22-item E-S-Qual model developed by Parasuraman et al. 
(2005) is adapted for Internet banking. Akınc1 et al. (2010) have operationalized E-S-Qual previously in the same service category. Questions adapted for Internet banking by Akınc1 et al. (2010) were taken into consideration in the model design of this study.

For future studies empirical testing of the model could be performed for the 20-item questionnaire proposed in this study. Further research may focus on the efficiency construct by the re-construction of items by enhancing the wordings of items to make customers differentiate the indicators. Parasuraman et al. (2005) have developed E-S-Qual for the settings which sell tangible products. By this study and by Akinci et al. (2010) research, E-S-Qual model is applied for service settings: Internet banking. However, banks have physical service encounters (branches) which can provide affective or emotional content and the high spatial proximity of service provider for customers whereas these are very low for Internet banking. Services provided through the physical settings of banks could have a substantial influence on customer satisfaction on e-banking services. However, there are service providers on the Internet which have no brick and mortar setting. Further empirical tests of E-S-Qual may be deployed on the totally virtual service settings.

\section{References}

1. Ajzen, I. (1991). The theory of planned behavior, Organizational behavior and human decision processes, 50 (2), pp. 179-211.

2. Akıncı, S., Atılgan-İnan, E. \& Aksoy, Ş. (2010). Re-assessment of E-S-Qual and ERecS-Qual in a pure service setting, Journal of Business Research, 63, pp. 232-240.

3. Barnes, S.J. \& Vidgen, R. (2001). An evaluation of cyber-bookshops: The WebQual method, International Journal of Electronic Commerce, 6, pp. 11-30.

4. Bauer, H.H., Falk, T. \& Hammerschmidt, M. (2006). eTransQual: A transaction process-based approach for capturing, Journal of Business Research, 59, pp. 876-885.

5. Boshoff, C. (2007). A psychometric assessment of E-S-Qual: A scale to measure electronic service quality, Journal of Electronic Commerce Research, 8, pp. 101-114.

6. Broderick, A.J. \& Supatra, V. (2002). Service quality in Internet banking: The importance of customer role, Marketing Intelligence and Planning, 20, pp. 325-335.

7. Connolly, R. \& Bannister, F. (2008). eTax filing \& service quality: The case of the revenue online service, World Academy of Science, Engineering and Technology, 38, pp. 313-317.

8. Connolly, R., Banister, F. \& Kearney, A. (2010). Government website service quality: A study of the Irish revenue online service, European Journal of Information Systems, 19, pp. 649-667.

9. Dixit, N. \& Datta, S.K. (2010). Acceptance of e-banking among adult customers: An empirical investigation in India, Journal of Internet Banking and Commerce, 15, pp. 1-17.

10. Durer, S., Özsüzgün-Çalışkan, A., Akbaş, H.E. \& Gündoğdu, C.E. (2009). Factors affecting the decision of using Internet banking: An investigation on Turkish bank customers, Marmara Üniversitesi I.I. .B.F. Dergisi, 26 (1), pp. 133-154.

11. El-Kasheir, D., Ashour, A.S. \& Yacout, O.M. (2009). Factors affecting continued usage of Internet banking among Egyptian customers, International Business Information Management Association (IBIMA), 9, pp. 252-263.

12. Fornell, C. \& Larcker, D.F. (1981). Evaluating structural equation models with unobservable variables and measurement error, Journal of Marketing Research, 18, pp. 39-50.

13. Fournier, S. \& Mick, D.G. (1999). Rediscovering satisfaction, Journal of Marketing, 63, pp. 5-23.

14. Grönroos, C. (1982). An applied service marketing theory, European Journal of Marketing, 16, pp. 30-48.

15. Lee, K.S., Lee, H.S. \& Kim, S.Y. (2007). Factors influencing the adoption behavior of mobile banking: A South Korean perspective, Journal of Internet Banking and Commerce, 12, pp. 1-9.

16. Lehtinen, U. \& Lehtinen, J.L. (1982). Service quality: A Study of quality dimensions. Unpublished working paper, Service Management Institute, Helsinki, Finland.

17. Lewis, R.C. \& Booms, B.H. (1983). The marketing aspects of service quality, American Marketing Association, pp. 99-107.

18. Loiacono, E.T., Watson, R.T. \& Goodhue, D.L. (2000). WebQualTM: A web site quality instrument. Working Paper. Worchester Polytechnic Institute.

19. Marimon, F., Vidgen, R., Barnes, S. \& Cristobal, E. (2010). Purchasing behavior in an online supermarket, the applicability of E-S-Qual, The Market Research Society, 52, pp. 111-129.

20. Ming-Chi, L. (2009). Factors influencing the adoption of internet banking: An integration of TAM and TPB with perceived risk and perceived benefit, Journal of Electronic Commerce Research and Applications, 8, pp. 130-141.

21. Oliver, R.L. (1981). Measurement and evaluation of satisfaction process in retail settings, Journal of Retailing, 57, pp. 25-48.

22. Parasuraman, A., Zeithaml, V.A. \& Berry, L.L. (1988). SERVQUAL: A multiple item scale for measuring consumer perceptions of service quality, Journal of Retailing, 64, pp. 12-40.

23. Parasuraman, A., Zeithaml, V.A. \& Malhotra, A. (2005). E-S-QUAL: A multiple item scale for assessing electronic service quality, Journal of Service Research, 7, pp. 213-233. 
24. Sasser, W.E., Olsen, R.P. \& Wyckoff, D.D. (1978). Management of service operations: Text, cases, and readings. Harvard University.

25. Suki, N.M. (2010). An empirical study of factors affecting the internet banking adoption among Malaysian consumers, Journal of Internet Banking and Commerce, 15, pp. 1-16.

26. Swaid, S.I. \& Wigand, R.T. (2009). Measuring the quality of e-service: Scale development and initial validation, Journal of Electronic Commerce Research, 1, pp. 13-28.

27. Szymanski, D.M. \& Hise, R.T. (2000). E-satisfaction: An initial examination, Journal of Retailing, 76, pp. $309-322$.

28. Tan, M. \& Teo, T.S. (2000). Factors influencing the adoption of internet banking, Journal of the Association for the Information Systems, 1, pp. 1-42.

29. Weitz, B.A. \& Wensley, R. (1985). Handbook of marketing. London: SAGE.

30. Wolfinbarger, M. \& Gilly, M.C. (2003). eTailQ: Dimensionalizing, measuring and predicting, Journal of Retailing, 79, pp. 183-198.

31. Yoo, B. \& Donthu, N. (2001). Developing a scale to measure the perceived quality of an Internet shopping site (SITEQUAL), Quarterly Journal of Electronic Commerce, 2, pp. 31-46, 175.

32. Zeithaml, V.A., Parasuraman, A. \& Malhotra, A. (2002). Service quality delivery through web sites: A critical review of extant knowledge, Journal of the Academy of Marketing Science, 30, pp. 362-375. 